\title{
Mincer Earnings Functions for the Netherlands 1962-2012
}

\author{
Joop Hartog ${ }^{1}$ • Sander Gerritsen ${ }^{2}$
}

(C) The Author(s) 2016. This article is published with open access at Springerlink.com

\begin{abstract}
We extract estimation results on the Mincer earnings function from four earlier studies and add new results from a recent dataset. We check for differences related to differences in earnings concepts and in sampling frame, to reduce bias in intertemporal comparison. Jointly, the studies show a clear U-shaped development in the rate of return to education from 1962 to 2012, with a bottom in the 1980s. We explain this from Tinbergens's race between suppy and demand (schooling and technology) and suggest this may be a widespread international pattern. Returns to potential experience show no marked time trend. The paper has been presented at the CPB-OCW Workshop "Returns to education: research and policy", The Hague, December 17 2015. We are grateful to Bas ter Weel and Harry Patrinos for comments on an earlier version and to Wiljan van den Berge and Dinand Webbink for providing us with their data. We also thank two anonymous referees for useful suggestions.
\end{abstract}

Keywords Returns to education - Mincer earnings equation · Race supply and demand

JEL Classification I26 $\cdot \mathrm{J} 24 \cdot \mathrm{J} 31$

\section{The Mincer Equation}

In the four decades since Jacob Mincer introduced his earnings function, as an implication of the theory of human capital, it has become a standard tool for analysing earnings

\footnotetext{
$凶$ Joop Hartog

j.hartog@uva.nl

1 University of Amsterdam, P.O. Box 15867, 1001 NJ Amsterdam, The Netherlands

2 CPB Netherlands Bureau for Economic Policy Analysis, Van Stolkweg 14, 2585 JR

The Hague, The Netherlands
} 
differences among individuals associated with schooling and experience (Mincer 1974; Becker 1964):

$$
\ln W=\beta_{0}+\beta_{1} S+\beta_{2} X+\beta_{3} X^{2}+\varepsilon
$$

$\mathrm{Ln} \mathrm{W}$ is the logarithm of an employee's wage rate per time unit, $\mathrm{S}$ is years of schooling, $\mathrm{X}$ is years of work experience and $\varepsilon$ is a residual for all other variables; some of these other variables may be explicitly specified (e.g. gender or region). Human capital theory gives the equation a well defined theoretical foundation. Under strict conditions, $\beta_{1}$ can be interpreted as the rate of return on investment in schooling: the return on invested foregone wages by going to school rather than going to work. Key conditions are perfect competition in the labour market, stationarity across cohorts, identical aptness among individuals to benefit from schooling (equal "ability"), negligible tuition and other direct cost of schooling, linearity of returns in years of schooling and separabity of log earnings in schooling and experience. $\beta_{2}$ and $\beta_{3}$ express the non-linear wage growth that is associated with continued investment after school, in on-the-job training. Because of easier data availability, $\mathrm{X}$ is commonly measured as potential experience: age minus age of graduation from highest level of schooling attended. In standard applications, years of schooling $\mathrm{S}$ is measured as the normal, nominal duration of an education. OLS estimates cannot be taken as measures of causal effects, essentially because benefits can only be inferred from individuals who differ in the amount of schooling they have chosen. ${ }^{1}$ Without the frame of human capital theory, the equation measures the effect of an extra year of schooling and the average effect of additional experience, from observations on inidividuals that differ in years of schooling and (potential) experience.

In its standard specification, the Mincer equation lends itself for convenient comparison over time and place. In this paper, we compare estimation results for the Netherlands over a period of half a century. This is useful as a description of historical developments of wage differentials on two important dimensions, it can produce concise observations that may be interesting enough to seek an explanation and it will generate information with high policy relevance, as the magnitude of wage differentials and the contribution of education to these differentials are important parameters in equity discussions. We have collected the results that are available from earlier studies and have added our own new estimates on the most recent data. We have paid tribute to the differences among the studies that may result from differences in sample composition and in definitions of the dependent variable. Results from the different studies cannot be simply put together in a time series of estimated coefficients. Yet, there is sufficient overlap among the studies to conclude to a $U$ shaped pattern of the returns to education and the absence of a clear time trend in the wage effect of experience. For an interpretation of the $U$ shaped returns to education we use Tinbergen's frame of a race between supply and demand, where initially supply shifts (expansion of education) are ahead, and later demand shifts (human capital intensive technological development) take the lead.

\footnotetext{
1 For discussion and references, see Hartog and van den Brink (2007) For the host of practical issues in data, variable definitions and specifications, see Harmon et al. (2001).
} 
In the next two sections we first present the datasets and then the estimation results from four established studies and from our own new study. Section 4 gives an interpretation of the observed U-shaped time profiles of the Mincer rate of return, Sect. 5 compares the profile to international evidence, Sect. 6 asks the question to what extent other or further explanations than a race between supply and demand are needed, and Sect. 7 discusses the proper econometric interpretation of Mincer returns estimated by OLS. Section 8 concludes.

\section{Data}

In this paper we present estimation results for The Netherlands from different studies for the period 1962-2012. ${ }^{2}$ Unfortunately, not all data have been collected in the same way and we have to face the issue of comparability.

$H_{O T}^{3}$., 1962-1989, CBS loonstructuuronderzoeken combined with NPAO and OSA surveys; gross.

For the period 1962-1989, data are from six samples of 10,000 or more observations, collected from company administrations by CBS (Central Bureau of Statistics, the national statistical agency). In 1962, 1965 and 1972 observations are sampled from male employees working in manufacturing, construction and banking, in 1979, 1985 and 1989 from all full-time working men. Up to 1972, there was a distinction among "employees", with monthly salary, and "labourers", with weekly wage, matching the then internationally common distinction among white-collar and blue-collar workers. The data are available as mean earnings in cross-tables with five levels of education and six-ten age groups.

In addition, for 1982, 1985, 1986 and 1988 HOT present results based on data collected by NPAO and OSA (government subsidised programs for labour market research). The data are from national surveys, each covering some 1200 respondents. Earnings are self-reported, not from administrative sources.

CBS has published separate cross-table data for labourers in 1972; the survey data for 1982 and 1988 allow to distinguish employees and labourers. Availability of these data permits to assess the effect of estimating returns on observations for employees only.

SOH ${ }^{4}$ : OSA, 1986-1996; net.

Estimates for the period 1986-1996 have been made on data from the bi-annual OSA Labour Market Panel. The data for each year cover some 4500 individuals aged 16-64. We present results on net hourly wages, as reported by respondents. Male respondents have a job of $34 \mathrm{~h}$ a week or more, among females, women with part-time jobs are included and the regressions include a dummy for part-time work (less than $35 \mathrm{~h}$ a week).

\footnotetext{
${ }^{2}$ We frequently cite verbatim from the source articles, without always specifying the exact location.

3 HOT: Hartog et al. (1993)

4 SOH: Smits et al. (2000); a selection of results has been published in Hartog et al. (1999).
} 
LO $O^{5}$ IALS 1994, NIPO 1999, gross.

Leuven and Oosterbeek (2000) use two different samples, a survey collected in 1999 by NIPO (an opinion research agency) and data from the IALS project in 1994 (International Adult Literacy Survey), both on gross hourly wages for 16-60 year olds. Note that in this case, the data for the two observations of a "time series" are not from the same sampling frame. The samples are rather small.

$J W^{6}$ : Loonstruktuuronderzoeken 1979-2002; gross.

Jacobs and Webbink (2006) analyse data from CBS Loonstructuuronderzoeken (Wage Structure Surveys) for 1979, 1985, 1989, 1996, 1997 and 2002: gross hourly wages from administrative sources, calculated by dividing gross monthly earnings by hours worked.

GH : CBS Panel Project, 1999-2012; gross.

We present newly estimated returns covering 1999-2012 on data from the CBS Labour Market Panel Project. We do not use panel observations, but a match of data in the EBB (Enquete Beroepsbevolking, Labour Force Survey) and data in the SSB (Sociaal Statistisch Bestand, ${ }^{8}$ Social Statistical Datasource). Earnings are fiscal earnings, taken from the income tax returns and hours worked have been obtained from EBB. Fiscal earnings are defined as Bruto Loon Sociale Verzekeringen (Gross Earnings Social Security, BLSV). Earnings have been divided by days worked as applied for Social Security purposes ( SV-dagen) and then divided by daily hours, to arrive at gross hourly wages. Respondents are 16-64 years old, the annual number of observations is between 25 and 30 thousand for men, and between 20 and 25 thousand for women.

\section{Results}

\subsection{Differences Associated with Differences in Datasets}

Estimates of rates of return on data from different sources, with different definitions and different sampling frames, cannot be combined at face value in a single time series. Estimated coefficients will generally be sensitive to definitions and sampled

\footnotetext{
5 LO: Leuven and Oosterbeek (2000),

$6 J W$ : Jacobs and Webbink (2006). We are grateful to Dinand Webbink for supplying us with his estimation results.

7 GH refers to our own estmates. Earlier estimations on the CBS panel project data were made by Webbink et al. (2013). They used annual rather than hourly wages, leading to rates of return also determined by hours worked. Moreover, years of education was incorrectly defined: the year of highest education level attained was not measured in the same year as wages were observed. Wiljan van den Berge (CPB) kindly provided the data.

8 For details on the data, see CBS (2012).
} 
Table 1 Mincer rates of return: estimates for identical years in different studies

\begin{tabular}{|c|c|c|c|c|c|c|c|c|c|c|}
\hline & & & \multicolumn{2}{|c|}{ HOT } & \multicolumn{2}{|c|}{$\underline{\mathrm{SOH}}$} & \multicolumn{2}{|l|}{ JW } & \multicolumn{2}{|l|}{$\mathrm{GH}$} \\
\hline & & & $\mathrm{m}$ & $\mathrm{m}$ & $\mathrm{m}$ & $\mathrm{v}$ & $\mathrm{m}$ & $\mathrm{v}$ & $\mathrm{m}$ & $\mathrm{v}$ \\
\hline 1979 & LS & gh25+ & 8.9 & & & & & & & \\
\hline 1979 & LS & gh & & & & & 6.4 & 6.0 & & \\
\hline 1982 & OSA & $\operatorname{gh} 25+$ & & 7.3 & & & & & & \\
\hline 1982 & OSA & gh & & 7.8 & & & & & & \\
\hline 1982 & OSA & nh & & 7.4 & & & & & & \\
\hline 1985 & LS & gh25+ & 7.2 & & & & & & & \\
\hline 1985 & LS & gh & & & & & 5.2 & 5.0 & & \\
\hline 1985 & OSA & $\mathrm{nh}$ & & 5.0 & & & & & & \\
\hline 1988 & OSA & gh25+ & & 5.9 & & & & & & \\
\hline 1988 & OSA & gh & & 6.1 & & & & & & \\
\hline 1988 & OSA & $\mathrm{nh}$ & & 5.5 & 6.1 & 6.0 & & & & \\
\hline 1989 & LS & gh25+ & 7.3 & & & & & & & \\
\hline 1989 & LS & gh & & & & & 5.0 & 4.5 & & \\
\hline 1996 & OSA & nh & & & 6.3 & 5.1 & & & & \\
\hline 1996 & OSA & gh & & & 7.5 & 5.6 & & & & \\
\hline 1996 & OSA & ny & & & 6.1 & 6.8 & & & & \\
\hline 1996 & OSA & gy & & & 7.3 & 7.8 & & & & \\
\hline 1996 & LS & gh & & & & & 6.1 & 6.2 & & \\
\hline 2002 & $\mathrm{CBSp}$ & gh & & & & & & & 8.0 & 7.2 \\
\hline 2002 & LS & gh & & & & & 7.5 & 7.5 & & \\
\hline
\end{tabular}

LS CBS Loonstruktuuronderzoek (Wage structure Survey)

CBSp CBS Panel Project

$g$ gross, $n$ net, $h$ hourly wage, $y$ annual wage, 25+ 25 years and older, $m$ men, $v$ women

populations and may give misleading information on changes in the wage structure. Hence, we will first try to assess effects of these differences. ${ }^{9}$

In one case (HOT), an effect has already been assessed by the original authors themselves. As noted above, the earliest estimates can be corrected for the restriction to employees only. By estimating the Mincer equation on data for employees only and for all workers, from the same data source in the same year, the authors conclude that estimates on employees only, underestimate returns by two percentage points. Experience profiles are not systematically under- or overestimated.

In Table 1 we present estimation results from different data sources in the same year. We also estimated several specifications on the data set used by Webbink, Gerritsen and Van der Steeg (see footnote 7); we do not present these results, but they have been taken into account in our conclusions.

Age restrictions on the sample have the same effect in all estimations: excluding respondents aged 15-25 reduces estimated rates of return. The exclusion eliminates

\footnotetext{
9 We do not report standard errors, as they have not been published in all studies. However, all coefficients are statistically significant at any conventional level, as authors usually note.
} 
in particular early working years of the low educated, when their earnings increase rapidly. Excluding their low earnings years reduces the gap with the higher educated, thus depressing the rate of return. The effect of exclusion is larger for women than for men.

Estimation on net wages generates lower rates of return than estimates on gross wages. This is plausible from progressive taxation. Yet, caution is warranted as all comparisons between net and gross are based on self-reported data and not on administrative data. Peculiarities of survey data may also play a role.

Comparing results from OSA data and CBS Wage Structure Survey data, both for 1996, both on gross hourly wages, both from datasets meant to be nationally representative, exposes a gap in estimated returns of +1.4 points for men and -0.6 points for women. As the OSA data are from household surveys and the CBS data from wage administrations, a gap between the two estimates should not come as a surprise; predicting magnitude and sign of the gap would be harder however.

With our CBS Panel Project data 1999-2012 we have made three estimates, both for men and for women: no conditions on hours worked, $35 \mathrm{~h}$ a week or more, or all hours but with a dummy for full-time ( $35 \mathrm{~h}$ or more). Among men, estimation with a full-time dummy has no effect on the estimated return to years in school, estimation for full-time workers only increases the schooling coefficient by $0.005-0.006$, ie half a percent point. Among women, including a full-time dummy raises the returns by about one percentage point. Estimation on full-time workers only leads to higher returns: a difference that gradually increases from two to three percentage points. Thus, full-time and part-time workers will not always enjoy identical rates of return, but intertemporal comparisons are influenced only slightly for women and not at all for men. Among women, the difference among estimates without sample constraints on weekly hours and a sample with weekly hours above 34 increases by just more than half a percentage point between 1999 and 2012. We have chosen to present our results on CBS Panel Project data from estimation on the sample without restriction on weekly hours worked.

The Mincer model distinguishes investment in formal schooling and in on-the-job training. To assess changes in the quadratic experience profiles of earnings, we use the estimates to calculate earnings growth over the first 10 years: $10 \beta_{2}+100 \beta_{3}$. Results are presented in Table 3.

Restricting the sample to workers over 25 years of age flattens estimated profiles, which comes as no surprise. The effect is visible in the OSA data 1982 and 1988 as analysed in the HOT study. It is also visible from the LS data for 1979, 1985 and 1989, but here, the comparison is based on different studies (HOT and JW). The profiles are also flatter for net earnings as compared to gross earnings (OSA 1982, 1988 and 1996), which again, given income tax rate progression, comes as no surprise, but the effect is mostly modest. Remarkably, profiles for women are mostly flatter than for men before 1999, and mostly steeper after 1999 (in the $G H$ study). This may be a composition effect on hours worked, as in the $G H$ study women's profiles are flatter than men's if only full-time workers are compared. The profiles estimated by $J W$ are remarkably steeper than in other studies, but this is due to specification: $J W$ estimate on age rather than potential experience. Smits, Odink and Hartog (2001, Tables 10.7 and 10.8) estimate on age and on potential experience (age minus schooling years minus 6) on the same data set (OSA 1996) and find much higher growth rate on age 
than on potential experience. For men, the linear terms are 0.081 versus 0.052 , for women 0.078 versus 0.041 .

\subsection{Indications for a Time Series}

Table 2 and Fig. 1 show the development of estimated Mincer returns since 1962. In the graph, we only connect estimates that emanate from a single study. For men, the composition of fragments merges into a clear pattern: an asymmetric U shape, starting with a decrease from the early 1960s towards a low in the early 1980s, followed by recovery and after 2007 turning into a mild decline. The swings are large. Just considering comparable data points, the initial decrease, from over $12 \%$ (when we add the correction for considering employees only) to some $7 \%$ is quite substantial, and the recovery during the 1990 s, from 5 to $7.5 \%$ is also strong. For women, with fewer data points, the pattern is not at variance with the U-shape observed for men, and the changes are also substantial. Both for men and for women, the increase from 1999 to the peak in the next decade is some one and a half percentage point. For both there is a decline during the most recent years.

Just as for the returns to schooling we have graphed (in Fig. 2) the ten-year profile slopes, connecting only the points that emanate from a single study. There are no unequivocal indications of trends in the profile slopes. Estimates differ among studies, but no single study has a clear trend, and the fragments do not merge into a single direction. At best, there is a very mild indication of a decling slope for women after 2000.

\section{A Simple Supply and Demand Interpretation}

The primary goal of this paper has been to document the development of the Mincer rate of return over half a century. But once the data are there, the temptation is irresistable to reflect on an interpretation. We will do so by simply checking whether the Tinbergen view of a race between supply and demand, i.e. between education and technology (Tinbergen 1975, Chapter 6), can fit the data. ${ }^{10}$ The feature we focus on is the U shaped development of returns: a decline followed by an increase. Returns will fall when the relative supply of higher educated labour increases faster than the relative demand is pushed up by increased knowledge intensity of production. In the declining stage, supply must have won, in the increasing stage demand must have won.

As Fig. 3 shows, the share of higher educated men and women in the labour force has continuously increased since $1960 .{ }^{11}$ It is less straightforward to measure demand for higher educated labour. We started by constructing an index of labour demand based on sectoral composition of employment. We calculated how many higher educated workers would have been hired if the share of higher educated labour within each industry would have been constant, while the employment share of each industry was allowed to follow its observed actual course. Hence, the index measures how demand

\footnotetext{
10 Katz and Murphy (1992) relate the change in the college wage premium in the US over a period of 25 years also to a race between supply and demand, without reference to Tinbergen, however.

11 Source: HOT (1960-1990); CBS Statline (2001, 2010).
} 
Table 2 Mincer rates of return: time series

\begin{tabular}{|c|c|c|c|c|c|c|c|c|c|c|c|c|}
\hline & & & \multicolumn{2}{|l|}{ HOT } & \multicolumn{2}{|c|}{$\mathrm{SOH}$} & \multicolumn{2}{|l|}{ JW } & \multicolumn{2}{|l|}{ GH } & \multicolumn{2}{|l|}{ LO } \\
\hline & & & $\mathrm{m}$ & $\mathrm{m}$ & $\mathrm{m}$ & $\mathrm{v}$ & $\mathrm{m}$ & $\mathrm{v}$ & $\mathrm{m}$ & $\mathrm{v}$ & $\mathrm{m}$ & $\mathrm{v}$ \\
\hline 1962 & LS & ghw25+ & 11.0 & & & & & & & & & \\
\hline 1965 & LS & ghw25+ & 10.2 & & & & & & & & & \\
\hline 1972 & LS & ghw25+ & 9.3 & & & & & & & & & \\
\hline 1979 & LS & gh25+ & 8.9 & & & & & & & & & \\
\hline 1979 & LS & gh & & & & & 6.4 & 6.0 & & & & \\
\hline 1982 & OSA & gh25+ & & 7.3 & & & & & & & & \\
\hline 1982 & OSA & gh & & 7.8 & & & & & & & & \\
\hline 1982 & OSA & $\mathrm{nh}$ & & 7.4 & & & & & & & & \\
\hline 1985 & LS & gh25+ & 7.2 & & & & & & & & & \\
\hline 1985 & LS & gh & & & & & 5.2 & 5.0 & & & & \\
\hline 1985 & OSA & $\mathrm{nh}$ & & 5.0 & & & & & & & & \\
\hline 1986 & OSA & $\mathrm{nh}$ & & 4.8 & 5.8 & 6.2 & & & & & & \\
\hline 1988 & OSA & gh25+ & & 5.9 & & & & & & & & \\
\hline 1988 & OSA & gh & & 6.1 & & & & & & & & \\
\hline 1988 & OSA & nh & & 5.5 & 6.1 & 6.0 & & & & & & \\
\hline 1989 & LS & gh25+ & 7.3 & & & & & & & & & \\
\hline 1989 & LS & gh & & & & & 5.0 & 4.5 & & & & \\
\hline 1990 & OSA & nh & & & 5.4 & 6.0 & & & & & & \\
\hline 1992 & OSA & $\mathrm{nh}$ & & & 5.6 & 5.3 & & & & & & \\
\hline 1994 & OSA & $\mathrm{nh}$ & & & 6.3 & 5.7 & & & & & & \\
\hline 1994 & IALS & gh & & & & & & & & & 5.7 & 5.7 \\
\hline 1996 & OSA & $\mathrm{nh}$ & & & 6.3 & 5.1 & & & & & & \\
\hline 1996 & OSA & gh & & & 7.5 & 5.6 & & & & & & \\
\hline 1996 & OSA & ny & & & 6.1 & 6.8 & & & & & & \\
\hline 1996 & OSA & gy & & & 7.3 & 7.8 & & & & & & \\
\hline 1996 & LS & gh & & & & & 6.1 & 6.2 & & & & \\
\hline 1997 & LS & gh & & & & & 6.6 & 6.6 & & & & \\
\hline 1999 & NIPO & gh & & & & & & & & & 8.0 & 9.0 \\
\hline 1999 & CBSp & gh & & & & & & & 7.2 & 6.5 & & \\
\hline 2000 & CBSp & gh & & & & & & & 7.4 & 6.5 & & \\
\hline 2001 & CBSp & gh & & & & & & & 7.9 & 6.9 & & \\
\hline 2002 & CBSp & gh & & & & & & & 8.0 & 7.2 & & \\
\hline 2002 & LS & gh & & & & & 7.5 & 7.5 & & & & \\
\hline 2003 & CBSp & gh & & & & & & & 8.1 & 7.0 & & \\
\hline 2004 & CBSp & gh & & & & & & & 8.0 & 6.6 & & \\
\hline 2005 & CBSp & gh & & & & & & & 8.3 & 7.0 & & \\
\hline 2006 & CBSp & gh & & & & & & & 8.4 & 7.2 & & \\
\hline 2007 & CBSp & gh & & & & & & & 8.9 & 7.3 & & \\
\hline 2008 & CBSp & gh & & & & & & & 8.8 & 7.6 & & \\
\hline
\end{tabular}


Table 2 continued

\begin{tabular}{|c|c|c|c|c|c|c|c|c|c|c|c|c|}
\hline & & & \multicolumn{2}{|c|}{ HOT } & \multicolumn{2}{|c|}{$\mathrm{SOH}$} & \multicolumn{2}{|c|}{ JW } & \multicolumn{2}{|c|}{$\mathrm{GH}$} & \multicolumn{2}{|c|}{ LO } \\
\hline & & & $\mathrm{m}$ & $\mathrm{m}$ & $\mathrm{m}$ & $\mathrm{V}$ & $\mathrm{m}$ & $\mathrm{V}$ & $\mathrm{m}$ & $\mathrm{V}$ & $\mathrm{m}$ & $\mathrm{v}$ \\
\hline 2009 & CBSp & gh & & & & & & & 8.9 & 7.6 & & \\
\hline 2010 & CBSp & gh & & & & & & & 8.8 & 7.9 & & \\
\hline 2011 & CBSp & gh & & & & & & & 8.7 & 7.3 & & \\
\hline 2012 & CBSp & gh & & & & & & & 8.4 & 7.2 & & \\
\hline
\end{tabular}

$g$ gross, $n$ net, $h$ hourly wage, $y$ annual wage, $w$ employees (white collar), 25+ 25 years and older, $m$ male, $v$ female

LS CBS Loonstruktuuronderzoek

CBSp CBS Panel Project

NIPO, IALS see text on $L O$

Table 3 Wage growth over the first 10 years $\left(10 \beta_{2}+100 \beta_{3}\right)$

\begin{tabular}{|c|c|c|c|c|c|c|c|c|c|c|}
\hline & & & \multicolumn{2}{|l|}{ HOT } & \multicolumn{2}{|l|}{$\mathrm{SOH}$} & \multicolumn{2}{|l|}{ JW } & \multicolumn{2}{|c|}{$\mathrm{GH}$} \\
\hline & & & $\mathrm{m}$ & $\mathrm{m}$ & $\mathrm{m}$ & $\mathrm{V}$ & $\mathrm{m}$ & $\mathrm{v}$ & $\mathrm{m}$ & $\mathrm{v}$ \\
\hline 1962 & LS & ghw25+ & .513 & & & & & & & \\
\hline 1965 & LS & ghw25+ & .490 & & & & & & & \\
\hline 1972 & LS & ghw25+ & .480 & & & & & & & \\
\hline 1979 & LS & $\operatorname{gh} 25+$ & .326 & & & & & & & \\
\hline 1979 & LS & gh & & & & & .636 & .593 & & \\
\hline 1982 & OSA & $\operatorname{gh} 25+$ & & .299 & & & & & & \\
\hline 1982 & OSA & $\mathrm{gh}$ & & .430 & & & & & & \\
\hline 1982 & OSA & $\mathrm{nh}$ & & .350 & & & & & & \\
\hline 1985 & LS & gh25+ & .328 & & & & & & & \\
\hline 1985 & LS & $\mathrm{gh}$ & & & & & .707 & .744 & & \\
\hline 1985 & OSA & $\mathrm{nh}$ & & .340 & & & & & & \\
\hline 1986 & OSA & $\mathrm{nh}$ & & .280 & .393 & .367 & & & & \\
\hline 1988 & OSA & gh25+ & & .300 & & & & & & \\
\hline 1988 & OSA & gh & & .370 & & & & & & \\
\hline 1988 & OSA & $\mathrm{nh}$ & & .350 & .421 & .372 & & & & \\
\hline 1989 & LS & gh25+ & .344 & & & & & & & \\
\hline 1989 & LS & gh & & & & & .727 & .731 & & \\
\hline 1990 & OSA & $\mathrm{nh}$ & & & .449 & .341 & & & & \\
\hline 1992 & OSA & $\mathrm{nh}$ & & & .397 & .282 & & & & \\
\hline 1994 & OSA & $\mathrm{nh}$ & & & .448 & .313 & & & & \\
\hline 1995 & & & & & & & & & & \\
\hline 1996 & OSA & $\mathrm{nh}$ & & & .443 & .344 & & & & \\
\hline 1996 & OSA & gh & & & .488 & .382 & & & & \\
\hline 1996 & OSA & ny & & & .433 & .184 & & & & \\
\hline 1996 & OSA & gy & & & .477 & .226 & & & & \\
\hline 1996 & LS & $\mathrm{gh}$ & & & & & .731 & .709 & & \\
\hline
\end{tabular}


Table 3 continued

\begin{tabular}{|c|c|c|c|c|c|c|c|c|c|c|}
\hline & & & \multicolumn{2}{|c|}{ HOT } & \multicolumn{2}{|c|}{$\mathrm{SOH}$} & \multicolumn{2}{|l|}{ JW } & \multicolumn{2}{|l|}{ GH } \\
\hline & & & $\mathrm{m}$ & $\mathrm{m}$ & $\mathrm{m}$ & $\mathrm{v}$ & $\mathrm{m}$ & $\mathrm{v}$ & $\mathrm{m}$ & $\mathrm{v}$ \\
\hline 1997 & LS & gh & & & & & .789 & .736 & & \\
\hline 1999 & $\mathrm{CBSp}$ & gh & & & & & & & .237 & .269 \\
\hline 2000 & CBSp & gh & & & & & & & .234 & .251 \\
\hline 2001 & CBSp & gh & & & & & & & .220 & .255 \\
\hline 2002 & CBSp & gh & & & & & & & .200 & .240 \\
\hline 2002 & LS & gh & & & & & .723 & .596 & & \\
\hline 2003 & CBSp & gh & & & & & & & .205 & .243 \\
\hline 2004 & CBSp & gh & & & & & & & .207 & .243 \\
\hline 2005 & CBSp & gh & & & & & & & .214 & .239 \\
\hline 2006 & CBSp & $\mathrm{gh}$ & & & & & & & .207 & .243 \\
\hline 2007 & CBSp & gh & & & & & & & .207 & .245 \\
\hline 2008 & $\mathrm{CBSp}$ & gh & & & & & & & .215 & .222 \\
\hline 2009 & CBSp & gh & & & & & & & .196 & .198 \\
\hline 2010 & $\mathrm{CBSp}$ & gh & & & & & & & .193 & .199 \\
\hline 2011 & CBSp & gh & & & & & & & .212 & .189 \\
\hline 2012 & CBSp & gh & & & & & & & .188 & .206 \\
\hline
\end{tabular}

$g$ gross, $n$ net, $h$ hourly wage, $y$ annual wage, $w$ white collar only, 25+ 25 years and older

$\beta_{2}, \beta_{3}$ : estimated coefficients of the quadratic experience profile

LS CBS Loonstruktuuronderzoek

CBSp CBS Panel Project

for higher educated labour would increase if employment shifts towards industries with high intensity of higher educated labour. ${ }^{12}$ As Fig. 3 shows, this cannot explain the upward movement of the rate of return. The shift towards high education industries only starts after 1970 (so, during the 1960s supply growth may have outpaced demand growth) but it tapers off after the early 1980s, when rates of return recover and supply continues to grow. To focus on technological development, we have looked for an index of ICT development. Changes in information and communication technology are generally recognised as the key drivers of structural changes in labour demand. Fig. 3 also graphs the index of the number of computer service and information technology agencies. ${ }^{13}$ Such firms barely existed during the 1960s and 1970s, but their number exploded after the mid-1990s. This suggests that it is not a shift towards knowledge-intensive industries but a shift towards knowledge-intensive production across the board that explains why a shifting supply curve has been overtaken by an even faster shifting demand curve. The interpretation of an economy-wide increase in knowledge intensity triggered by economy-wide application of new ICT technology matches simple day-to-day observations as well as results in the international literature. It is also in line with results on economy-wide polarisation in the Dutch labour

12 Source: CBS Statline, Werkzame Beroepsbevolking; vergrijzing per bedrijfstak SBI 2008 (dd 17 maart 2014) en Statistisch Zakboek 1964.

13 Source: CBS Statline, Bedrijven naar activiteit SBI 93, K 72. 


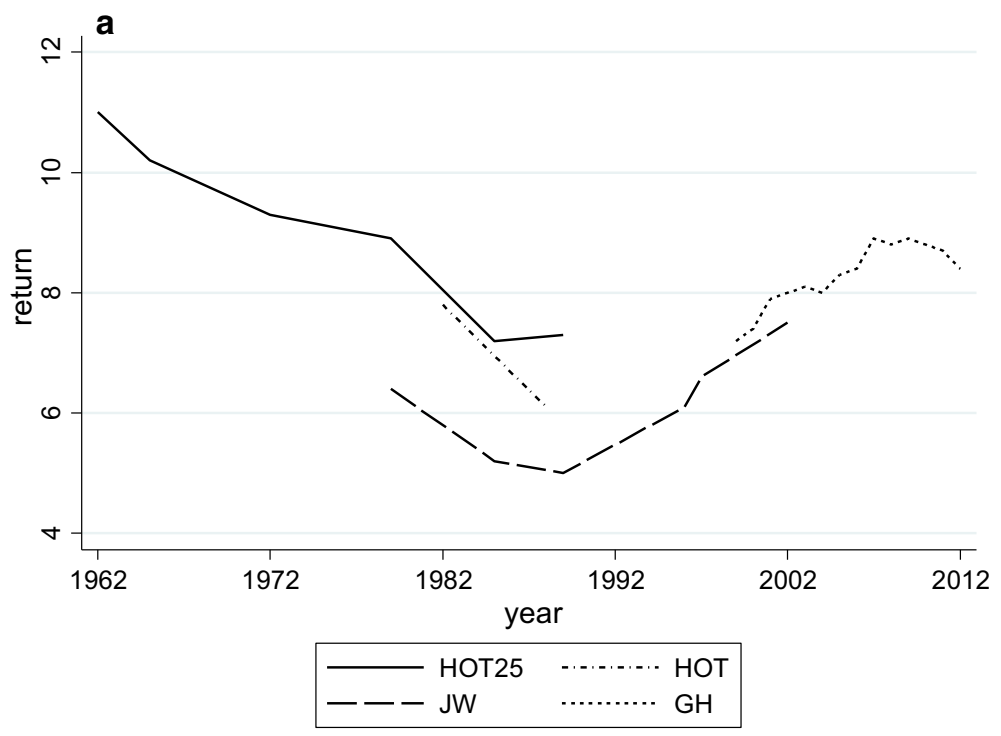

b

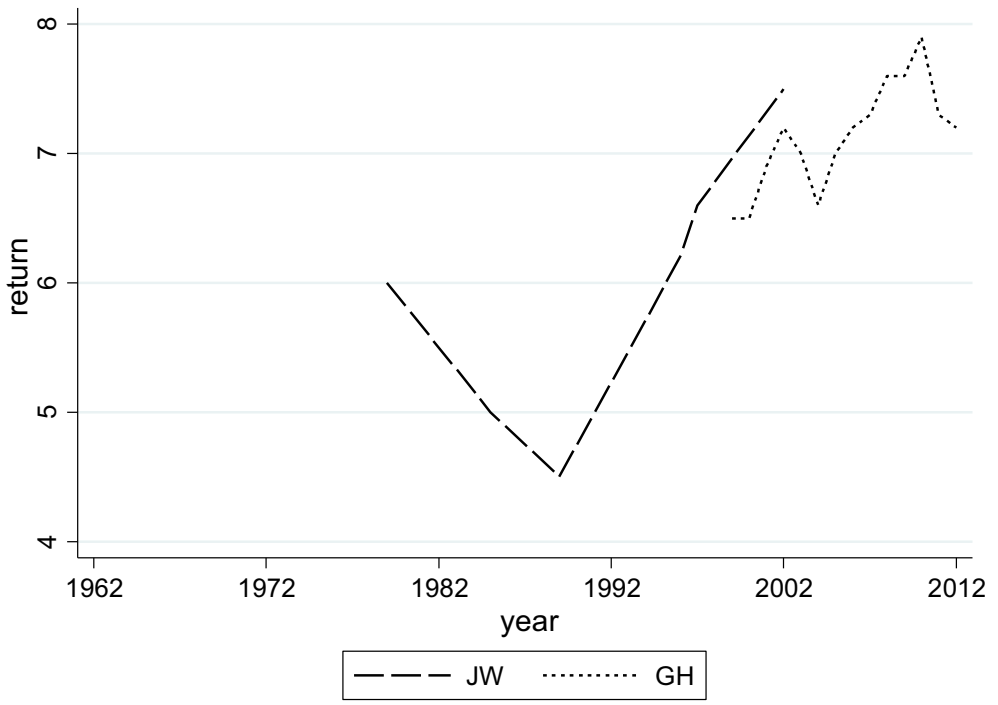

Fig. 1 a Mincer returns to schooling: men, b Mincer returns to schooling: women, Source: Table 2

market as reported by Smits and de Vries (2015). They find that between 1996 and 2011, polarisation has increased in the sense that the share of low-pay jobs and the share of high-pay jobs have both increased while the share of middle-pay jobs has decreased. The interpretation is that computerisation can take over cognitive routine jobs in the middle segment. Low-pay jobs, often involving non-cognitive manual routine jobs (like personal services) and high pay jobs, involving cognitive non-routine jobs are less easily substituted by computerisation. The polarisation is not due to a 

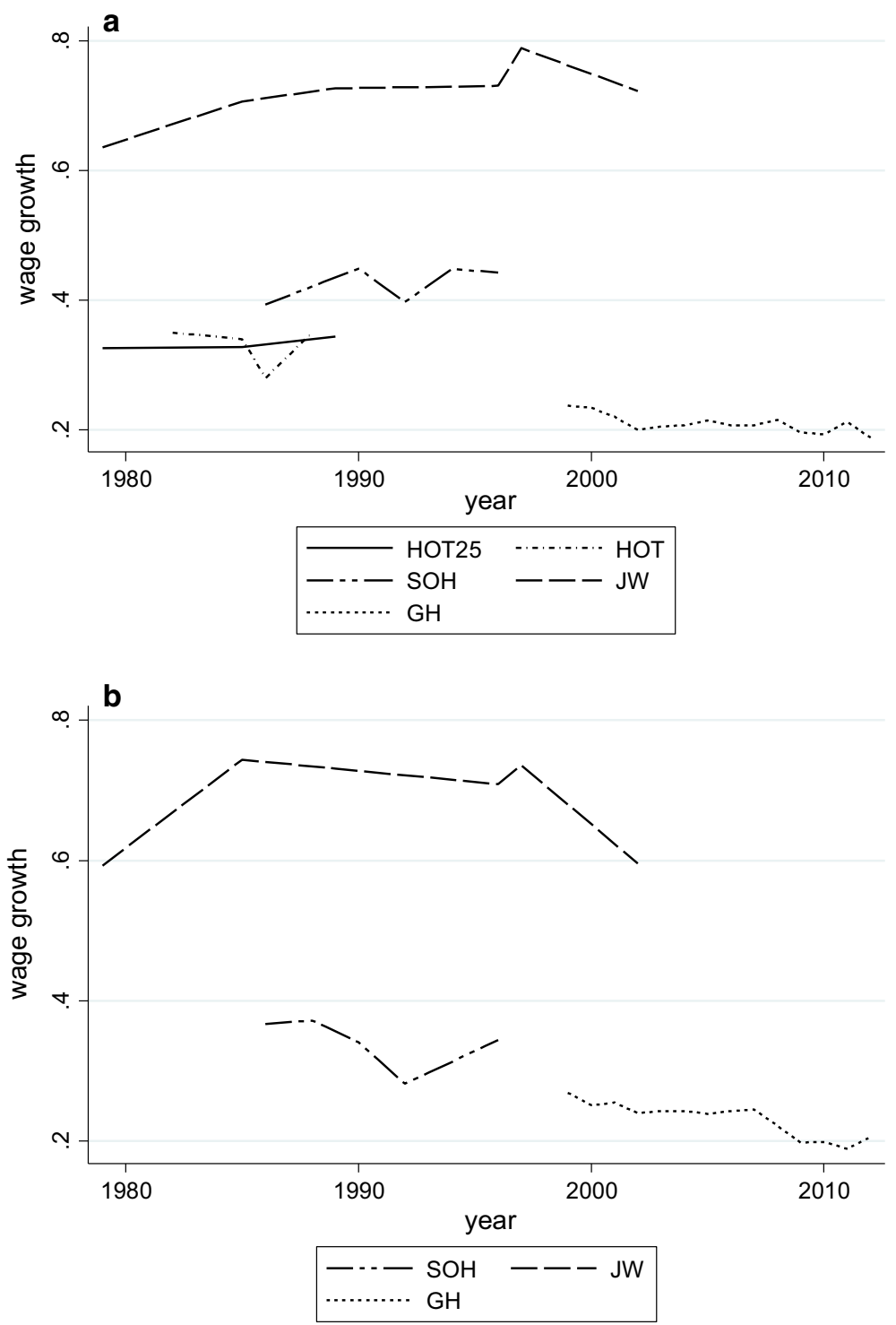

Fig. 2 a Predicted wage growth during the first 10 years: men, b predicted wage growth during the first 10 years: women, Source: Table 3

shift of employment among four main industrial sectors (agriculture, manufacturing, commercial services and non-commercial serviceses), but operates within each sector. Unfortunately, developments before 1996 have not been measured.

\section{International Comparison}

Montenegro and Patrinos (2014) estimated rates of return for 139 countries using 819 household surveys standardised for maximum comparability. The international annual 

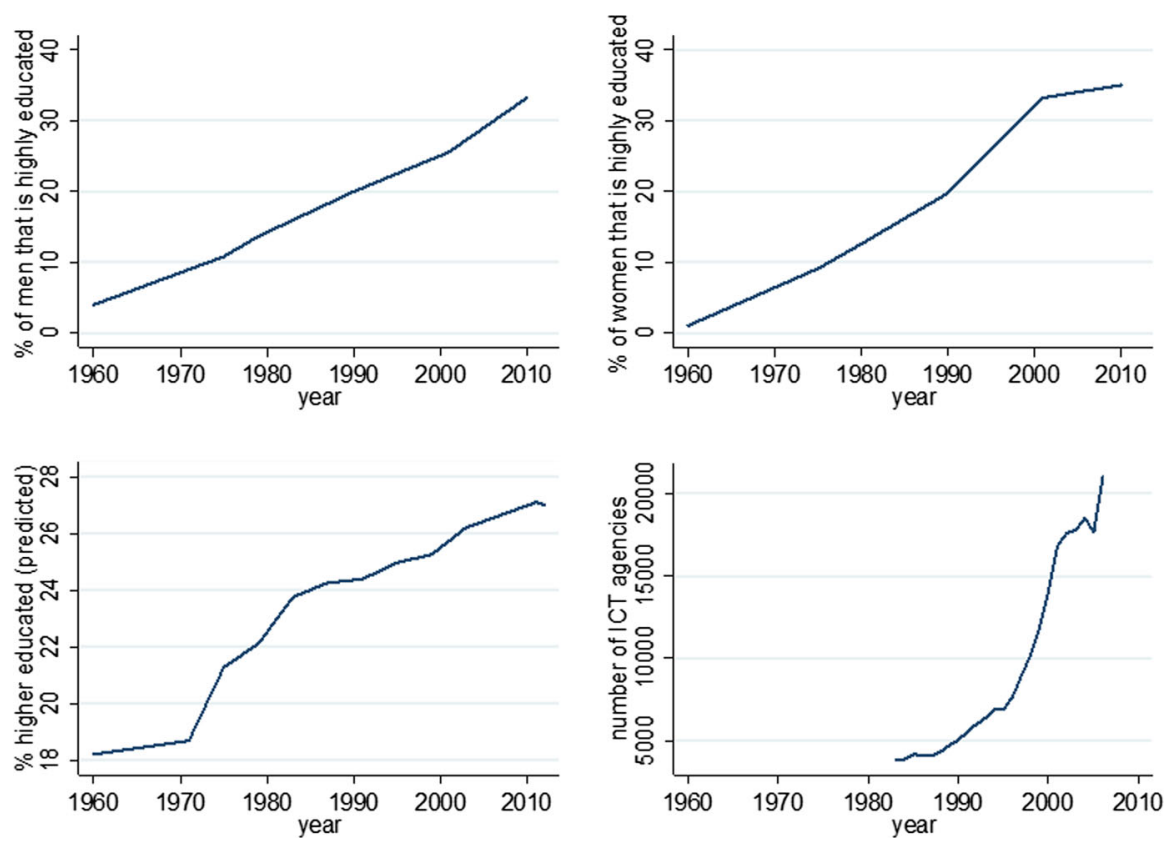

Fig. 3 Supply and demand higher educated labour, the top two graphs depict the percentage share of the labour force with tertiary education. The bottom graph shows the share of tertiary educated labour in the total labour force if within industries the shares would be constant at their values in 2014 (left graph) and the number of ICT firms (right graph). Data sources in "Appendix"

mean shows a gradual decline from the early 1980s to around 2000 and stabilisation since then. However, it is hard to tell how important composition effects are, as the means have not been calculated for a constant set of countries. ${ }^{14}$

Heckman et al. (2005) present estimates of the same standard Mincer earnings function as we use, on U.S. Census data spanning the years 1940-1990. For white men, the return to education is remarkably constant across five decades: $12.5,11$, 11, 12, 10 and 13\%. Still, the last three values, relating to 1970, 1980 and 1990, indicate a U-shaped pattern as observed for The Netherlands and the increase between 1980 and 1990, by $30 \%$, is substantial. For black men, the estimated return increases monotonically, from 9 to $15 \%$.

Harmon et al. (2001, p 16) classify results from more than 1000 studies (!) on Europe and the United States. Their graph shows a similar U- shaped pattern as we report here: a marked decline from the 1960s to the 1970s, a further decline to the 1980 s and then recovery in the 1990s.

\footnotetext{
14 Inspection of time series for separate countries shows a variety of patterns and certainly no dominant U-shape. Several countries from EUROSTAT which enter the sample at the end of the period (around 2004), have low returns, so composition effects may well be relevant. This private communication from Harry Patrinos is gratefully acknowledged.
} 


\section{Further Explanations}

While the supply and demand framework is an obvious start for an economic analysis of changes in the structure of wages, it is equally obvious that we should not be blind to its limitations. Of course, there is a long list of factors that may explain changes in the rate of return to education. However, we have a specific focus on a broad feature of the developments, the U-shaped pattern observed over five decades. International evidence seems to confirm that this is a global development and this calls for considering factors that operate worldwide. The simple supply and demand framework seems to match this global development quite well. Growing participation in higher education is a world wide development, interestingly enough precisely in the period we cover. As Shofer and Meyer (2005, p 3) note: "Participation in higher education has been growing at high rates in virtually every country in the world.... The bulk of the growth occurred after 1960, in just the last four decades." Similarly, the ICT revolution is a global phenomenon. It would be a broad and bold step, however, to suggest that the race between supply and demand, or education and technology, has developed at the same pace everywhere. Acemoglu and Autor (2012), in their review of Goldin and Katz's book that squarely adopts the Tinbergen race as their key frame of analysis, agree that this model does a good job in explaining the development of the college/high school wage premium during the twentieth century. In the US, the increased college premium in recent decades is not ascribed to speeding up of technological development, but to slowing down of the growth in college participation. But the key implication is that Tinbergen's race model is a very fruitful approach.

A little reflection suggests that other, specific Dutch potential explanations probably will not carry much weight in undermining our interpretation of the observed time profile. One might think that the business cycle has some influence: the bottom of the U-shape coincides with high unemployment and the modest decline in rates of return in recent years may be related to the recession that developed after 2008. In fact however, the relationship between rate of return and the business cycle is poorly known (Corliss et al. 2013). Labour market institutions may have an impact on the wage structure as the relative bargaining power of educational groups may shift over time. However, there have not been significant changes in the system of wage bargaining; union membership rates have fluctuated, but coverage by collective bargaining has been fairly constant. Socio-economic policies may have some effect, as social protection at the bottom (minimum wages, unemployment and disability entitlements and benefits) has weakened after the 1980s: less policy support for the lower wages may increase the rate of return. The schooling system has been restructured, with softening the rigid selection of pupils right after grade school but this was precisely motivated by a desire to facilitate more participation in advanced education: it would merely help to explain the increased supply of higher educated labour. While each of these factors may have an impact on the wage structure by education, whether compressing or elongating, it is unclear a priori how their interaction would precisely generate the observed U-shaped profile of returns.

A deeper analysis would certainly be interesting. Shifting demand curves can be related to changes in the nature of job tasks and in job requirements, adding the dynamic perspective to an analysis as in Hartog (1980), in the vein of Autor et al. (2003). 
The notion of shifting supply curves can be backed up by a more detailed analysis of a changing differentiaton of the labour force by abilities, skills and personality. Horizontal differentiaton of job requirements and types of education can also enrich the picture. It would be interesting, for example, to trace the effects of technological change and distinguish primary effects from spill-overs to jobs with less scope for productivity increase (like teaching or live entertainment). But these would all be additional analyses rather than alternative explanations. Essentially, the race between shifting supply and demand curves seems an excellent starting point for understanding the U-shaped time profiles of the Mincerian rate of return to education.

\section{Some Limitations of Our Analysis}

Our main goal in this paper is to expose a consistent picture of changes in the wage structure by education and experience as it can be drawn up from a series of estimates of the Mincer equation. The Mincer equation is routinely used as a convenient summary of that structure. But of course we should not forget its limitations.

In a much more extensive and profound analysis than ours of 50 years of Mincer equations for men in the US, Heckman et al. (2005) quantify limitations of Mincer estimates of the rate of return. Statistical tests show that separability of schooling and experience does not hold: profiles differ by education. Calculations of internal rates of return from estimated earnings functions allowing for these interactions and giving up linearity in the schooling effect show large variations in the rates of return to sequential steps in schooling careers, thus rejecting the imposition of constant marginal returns to years of schooling. Not surprisingly, a single schooling coefficient can hide large variation. In 1940, the single Mincer coefficient for white men is $12.5 \%$, while estimating marginal returns for sequential steps of two additional schooling years each, from 6 to 16, leads to the series 12, 14, 24, 8 and 15\%; in 1990, the linear Mincer return is $13 \%$, while the step series is $19,19,47,8$ and $12 \%$. There are also large and variable gaps among internal rates of return calculated from estimated Mincer equations or from observed mean earning by schooling and experience cells. The effect of including tuition cost and taxes on men's return to schooling is actually rather mild; the largest reductions relate to the highest level of education, in particular for black men. No doubt, similar heterogeneity and sensitivity of returns can be found for the Netherlands.

As noted, OLS Mincer estimates cannot be taken at face value as measuring causal effects. But the literature has not yet established a robust uniform estimate of the magnitude of endogeneity bias. In 1999, David Card concluded from a survey of IV studies that "the average (or average marginal) return to education in a given population is not much below the estimate that emerges from a simple cross-section regression of earnings on education. The "best avaliable" evidence ... suggest a small upward bias (on the order of 10\%) in the simple OLS estimates" (Card 1999, p. 1855). Card suggests that the ability bias is modest and emphasises that IV corrections are sensitive to the type of instruments used. Rates of return to education are heterogeneous, and through their choice of instruments, IV corrections target different segments of the distribution. Heckman et al. (2005) are very critical on the value of IV estimates, arguing that instruments are mostly very weak. 
A few studies focus on institutional reforms in The Netherlands to asses causal effects. Webbink (2007) uses the reduced duration of university studies in 1982 from five to four years to estimate a rate of return to the fifth year at university at some 7-9\% in the mid 1980s. This is somewhat higher than the Mincer OLS estimates presented here, but lower than the Mincer OLS return to a year of university education that is also estimated by Webbink, at $11 \%$. Oosterbeek and Webbink (2007) estimate that an extension of lower technical education, from three to four years, brings zero wage benefits; they explain this from adding more general education to vocational training that in this segment brings no productivity gain. These local effects illustrate again the heterogeneity in returns across levels and types of education that may well be more important than endogeneity bias.

For our purpose, the key question is to what extent endogeneity bias is constant over time. With a constant bias, the Mincer estimates would adequately reflect intertemporal development. As far as we know, there is only one study that compares a time series of OLS estimates with a time series of IV estimates using the same instruments in each year. Sousa et al. (2015) use quarter of birth as instrument to estimate returns to schooling in Portugal for each year from 1986 to 2009. Not only the level differs among OLS and IV, but trends also differ. That would suggest that Mincer OLS estimates do not track the time profile of causal effects identified with birth quarter as instrument. Taber (2001) analyses the rise in the college premium in the US from early to late 1980s' and concludes from IV, Heckman two-step and structural dynamic programming modelling that the causal effect of college attendence has not changed but that returns to unobserved ability have increased (the return to observed ability, i.e. AFQT score, has not changed); however, estimation (and interpretation) of the dynamic programming model is marred by a problem of multiple optima. Taber's conclusion would fit in with the the dominant view of the time, but Cawley et al. (1998) do not agree that the increase in the college premium in the US would be due to an increase in the return to ability. They show that the result is not robust and point to two serious identification problems: the effects of time and age cannot be disentangled, and strong sorting of education by ability leaves most education-ability combinations unobserved. They reject the linear models that have been applied and conclude from their own non-parametric estimates that in the mid-80s the college premium has increased for young white males of high ability, but that little can be said for other ability groups. Clearly, we have insufficient robust knowledge to infer a time profile of causal effects of schooling from the time profile of Mincer OLS estimates.

\section{Conclusion}

After assessing comparability of a number of studies on the Mincer earnings function in the Netherlands, we can confidently draw two clear conclusions, both for men and for women: over a period of five decades since 1960, the rate of return to education has followed a U shaped pattern with bottom in the mid-1980s, while the slopes of earnings-experience profiles have not changed. The U-shape can be explained with Tinbergen's race between supply and demand: initially the growth of participation in higher education outpaced the growth in demand, while later the ICT revolution 
pushed out the demand curve faster than the supply curve. This history is similar to international developments.

In spite of its elegant theoretical underpinning, we should not forget that essentially, the Mincer rate of return is a convenient summary statistic of the wage structure by level of education. Log-linearity in years of schooling is a simplification that hides much variation. On changes in the causal effect of education on wages we cannot draw firm conclusions

Open Access This article is distributed under the terms of the Creative Commons Attribution 4.0 International License (http://creativecommons.org/licenses/by/4.0/), which permits unrestricted use, distribution, and reproduction in any medium, provided you give appropriate credit to the original author(s) and the source, provide a link to the Creative Commons license, and indicate if changes were made.

\section{Appendix}

Supply: Share of Tertiary Educated in the Labour Force

\begin{tabular}{lllllll}
\hline & 1960 & 1975 & 1979 & 1990 & 2001 & 2010 \\
\hline Male & 4.0 & 10.8 & 13.6 & 20.0 & 25.5 & 33.2 \\
Female & 1.0 & 9.1 & 11.9 & 19.8 & 33.2 & 35.0 \\
\hline
\end{tabular}

Source: HOT (1960-1990); CBS Statline (2001, 2010)

\section{Supply: Aggregate Share of Tertiary Educated if Shares Within Industries were Constant}

Share of higher educated in the labour force if the share of higher educated within industries is held constant at the level in 2001, and employment across industries shifts over time as observed

\begin{tabular}{lllllllllllll}
\hline 1960 & 1971 & 1975 & 1979 & 1983 & 1987 & 1991 & 1995 & 1999 & 2003 & 2007 & 2011 & 2012 \\
18.20 & 18.69 & 21.29 & 22.11 & 23.75 & 24.25 & 24.40 & 24.97 & 25.26 & 26.21 & 26.66 & 27.09 & 27.02 \\
\hline
\end{tabular}

Sources

Share higher educated in labour force by industry 2001: CBS Statline, Werkzame Beroepsbevolking; vergrijzing per bedrijfstak SBI 2008 (dd 17 maart 2014), Totaal M/V, 1+, totaal herkomstgroepering, totaal werkzame beroepsbevolking

Share labour force by industry: 1971-2012: idem, idem, SBI 93

Share labour force by industry 1960: Statistisch Zakboek 1964, H74, p 40. Added: werknemers Gemeente (H78, p 43), Rijk (H77, p 44) voor Sector Overheid, afgezonderd van "Overige dienstverlening"; Restant "Overige dienstverlening" samengevoegd met "Huiselijke diensten".

Share higher educated added up to Aggregate 1960, weight of subgroups 1971:

Handel, Bank Verzekering $=\mathrm{G}+\mathrm{J}$

Overig $=\mathrm{H}+\mathrm{K}+\mathrm{M}+\mathrm{N}+\mathrm{O}$

Datasources: CBS statline

Labour force by industry: Werkzame beroepsbevolking; vergrijzing per bedrijfstak SBI '93; verslagperiode 1971-2013; 14 maart 2014

Share higher educated: Werkzame beroepsbevolking; vergrijzing per bedrijfstak SBI 2008; 14 maart 2014 


\section{Demand: Computer service and Information Technology Agencies}

\section{Copied from CBS Statline}

72 Computerservice- en informatietechnologiebureaus e.d.

\begin{tabular}{|c|c|}
\hline $\begin{array}{l}\text { Onderwerpen } \sqrt{x} \\
\text { Perioden } \pi\end{array}$ & $\begin{array}{l}\text { Bedrijven naar activiteit SBI'93 } \\
\text { K Verhuur } \\
72 \text { Computerservice, informatietechnol. } \\
\text { Absoluut }\end{array}$ \\
\hline 1983 & 3830 \\
\hline 1984 & 3880 \\
\hline 1985 & 4180 \\
\hline 1986 & 4100 \\
\hline 1987 & 4105 \\
\hline 1988 & 4330 \\
\hline 1989 & 4725 \\
\hline 1990 & 5060 \\
\hline 1991 & 5540 \\
\hline 1992 & 5970 \\
\hline 1993 & 6390 \\
\hline 1994 & 6925 \\
\hline 1995 & 6885 \\
\hline 1996 & 7680 \\
\hline 1997 & 8965 \\
\hline 1998 & 10,180 \\
\hline 1999 & 11,835 \\
\hline 2000 & 14,020 \\
\hline 2001 & 16,770 \\
\hline 2002 & 17,560 \\
\hline 2003 & 17,790 \\
\hline 2004 & 18,495 \\
\hline 2005 & 17,630 \\
\hline 2006 & 21,000 \\
\hline
\end{tabular}

\section{References}

Acemoglu, D., \& Autor, D. (2012). What does human capital do? A review of Goldin and Katz's the race between education and technology, Journal of Economic Literature, 50(2), 426-463.

Autor, D., Levy, F., \& Murnane, R. (2003). The skill content of recent technological change: An empirical exploration. The Quarterly Journal of Economics, 118(4), 1279-1333.

Becker, G. (1964). Human capital. Chicago: University of Chicago Press.

Card, D. (1999). The causal effect of education on earnings. In O. Ashenfelter \& D. Card (Eds.), Handbook of labor economics (Vol. 3A). Amsterdam: North-Holland.

Cawley, J., Heckman, J., \& Vytlacil, E. (1998). Cognitive ability and the rising return to education, Boston: NBER Working Paper 6388

CBS (2012) Centrum voor Beleidsstatistiek, Documentatierapport Arbeidsmarktpanel 1999-2009V1, 30 maart 2012.

Corliss, M., Lewis, P., \& Daly, A. (2013). The rate of return to higher education over the business cycle. Australian Journal of Labour Economics, 16(2), 219-236. 
ESB (2015). Dossier Activerende Sociale Zekerheid, Economisch-Statistische Berichten, 2015 (47065), 26 maart

Harmon, C., Walker, I., \& Westergaard-Nielsen, N. (Eds.). (2001). Education and earnings in Europe. Cheltenham UK: Edward Elgar.

Hartog, J. (1980). Earnings and capability requirements. Review of Economics and Statistics, LXII, 2, $230-240$.

Hartog, J., Odink, J., \& Smits, J. (1999). Rendement op scholing stabiliseert, Economisch-Statistische Berichten, 84 (4215), 13 augustus. 582-584

Hartog, J., Oosterbeek, H., \& Teulings, C. (1993). Age, wages and education in the Netherlands. In P. Johnson \& K. Zimmermann (Eds.), Labour markets in an ageing Europe. Cambridge, UK: Cambridge University Press.

Hartog, J., \& van den Brink, H. Maassen (Eds.). (2007). Human capital, theory and evidence. Cambridge, UK: Cambridge University Press.

Heckman, J., Lochner, L., \& Todd, P. (2005) Earnings functions, rates of return and treatment effects: The Mincer equation and beyond, Bonn: IZA Discussion Paper 1700

Jacobs, B., \& Webbink, D. (2006). Rendement onderwijs blijft stijgen, Economisch-Statistische Berichten, 91 (4492), 25 augustus, 406-407

Katz, L., \& Murphy, K. (1992). Changes in relative wages, 1963-1987: Supply and demand factors. The Quarterly Journal of Economics, 107(1), 35-78.

Leuven, E., \& Oosterbeek, H. (2000). Rendement van onderwijs stijgt, Economisch-Statistische Berichten, 85 (4262). 23 juni, 523-524

Mincer, J. (1974). Schooling, experience and earnings. New York: Columbia University Press for National Bureau of Economic Research.

Montenegro, C., \& Patrinos, H. (2014). Comparable Estimates of Returns to Schooling Around the World, Washington: World Bank Policy Research Working Paper 7020

Oosterbeek, H., \& Webbink, D. (2007). Wage effects of an extra year of basic vocational education. Economics of Education Review, 26(4), 408-419.

Shofer, E., Meyer, J. (2011). The World-Wide Expansion of Higher Education, Stanford University, CDDRL Working Papers 32

Smits, J., Odink, J., \& Hartog, J. (2000). New results on returns to education in The Netherlands, unpublished note. Amsterdam: Department of Economics and Econometrics, University of Amsterdam.

Smits, J., Odink, J., \& Hartog, J. (2001). The Netherlands. In Walker Harmon \& Westergaard-Nielsen (Eds.), Education and earnings in Europe. Cheltenham, UK: Edward Elgar.

Smits, W., \& de Vries, J. (2015). Toenemende polarisatie op de Nederlandse arbeidsmarkt, EconomischStatistische Berichten 100 (4701), 8 januari, 24-25

Sousa, S., Portela, M., \& Sa, C. (2015). Characterization of returns to education in Portugal: 1986-2009, Working Paper Catolica Lisbon School of Economics and Business

Taber, C. (2001). The rising college premium in the eighties: Return to college or return to unobserved ability? The Review of Economic Studies, 68(3), 665-691.

Tinbergen, J. (1975). Income distribution. Amsterdam: North Holland.

Webbink, D. (2007). Returns to University education: Evidence from a Dutch institutional reform. Economica, New Series, 74(293), 113-134.

Webbink, D., Gerritsen, S., \& van der Steeg, M. (2013). Financiële opbrengsten onderwijs verder omhoog, Economisch-Statistische Berichten 98 (4651). 11 januari, 13-15 